\title{
Extraction, Isolation, Characterization and Antibacterial Activity Test of an Alkaloid Constituent from Seeds of Calpurnia Aurea
}

\author{
Tariku Nefo Duke \\ Department of Chemistry, College of Natural and Computational Sciences, University of Wolaita Sodo, \\ P.O. Box, 138, Ethiopia
}

\begin{abstract}
By different solvent extractions and chromatographic techniques an alkaloid constituent compound A1 was isolated from seeds of Calpurnia aurea. Infrared spectroscopy, mass spectroscopy and nuclear magnetic resonance studies showed that the isolated compound A1 was chemically: 1-(2,4-bis(dimethylamino)cyclopentyl)heptan-4one, $\mathrm{C}_{16} \mathrm{H}_{32} \mathrm{~N}_{2} \mathrm{O}$ and the study revealed that the pure isolated compound have a wide range antibacterial activity (MIC of 25.8 to $78 \mathrm{mg} / \mathrm{mL}$ ) against all tested bacteria strains.

Keywords: Calpurnia aurea; alkaloid; characterization; antibacterial activity.

DOI: $10.7176 / \mathrm{JNSR} / 9-23-06$

Publication date: December $31^{\text {st }} 2019$

\section{Introduction}

Calpurnia aurea is a Southern African tree belonging to the family Fabaceae, occurring along the coastal regions from the south-eastern Cape northwards and inland to the central Transvaal, with an isolated population in eastern Zimbabwe. Mostly found as a small tree up to $4 \mathrm{~m}$, but under forest conditions reaching heights of $15 \mathrm{~m}$. This species produces abundant sprays of bright yellow flowers. Leaves are pinnately compound with a terminal leaflet (imparipinnate). Pods are thin and papery, straw-coloured and about $10 \mathrm{~cm}$ in length [1]. Calpurnia aurea is one of the medicinal plant which presumptive folklore use prescribed for snake bite and anti-cancer especially effective against snake bite in the researcher area. Based on this on its medicinal value, the researcher is very interested to investigate active chemical constituents available in the plant, especially by using the most polar solvent. In this paper 1D NMR techniques were used to assign the NMR signals of the isolated alkaloid constituent compound A1, including ${ }^{1} \mathrm{H}$ NMR, ${ }^{13} \mathrm{C}$ NMR, DEPT-135, IR and LC-MS spectra and antibacterial activity of the isolated compound $\mathrm{A} 1$ was analyzed.
\end{abstract}

\section{Materials and Methods \\ Plant Collection and Identification}

The seeds of Calpurnia aurea were collected from southern nations, nationalities, and peoples' region of Ethiopia around Wolaita Sodo University campus, which is $333.5 \mathrm{~km}$, south of Addis Ababa. The plant was identified by botanist in the department of biology, Wolaita Sodo University.

\section{Instruments}

${ }^{1} \mathrm{H}$ NMR $\left(400 \mathrm{MHz}, \mathrm{CDCl}_{3}\right)$ and ${ }^{13} \mathrm{C} \mathrm{NMR}\left(100 \mathrm{MHz}, \mathrm{CDCl}_{3}\right)$ spectra were recorded on a Bruker ARX- NMR spectra and with TMS as an internal standard (chemical shifts in $\delta, \mathrm{ppm}$ ). The isolated compound A1 was dissolved in $\mathrm{CDCl}_{3}$ and analyzed with one-dimensional NMR (proton ${ }^{1} \mathrm{H}$, carbon ${ }^{13} \mathrm{C}$ ). ESI- MASS/MS spectra were recorded on an LC-MS mass spectrometer.

\section{Extraction and isolation}

The air-dried seeds of Calpurnia aurea (200 g) were extracted with one liter of $n$-hexane, ethyl acetate and methanol successively.

The methanol soluble crude extract $(5.2 \mathrm{~g})$ was chromatographed on silica gel $(180 \mathrm{~g})$ using gradient elution with $n$-hexane-ethyl acetate form (10:1 to 1:1). TLC showed fractions number 10,11,12 and 13 analyzed with the same $\mathrm{R}_{\mathrm{f}}$ value and the same characteristic color on TLC were combined, then applied on PTLC using methanolchloroform (7:3) and resulting in the isolation of two compounds the top band A1 (48.6 mg) a single spot $R_{f}$ value 0.79 and next to the top band $\mathrm{A} 2(19 \mathrm{mg})$ black spot $\mathrm{R}_{\mathrm{f}}$ value 0.43 were collected.

\section{Determination of minimum inhibitory concentration (MIC)}

The minimum inhibitory concentration (MIC) of an alkaloid constituent compound A1 from Calpurnia aurea was evaluated according to method described [2] [3].

\section{Preliminary phytochemical analysis}

Phytochemical screening tests were done to determine the class of compounds present in the crude extract of methanol by following the standard procedures [4] [5]. 


\section{Results and discussion}

The phytochemical screening test of the methanol crude extract revealed the presence of alkaloids, tannins, flavonoids and saponins, terpenoids, phenols and anthraquinones.

Chromatographic purification of the methanol extract gave compound coded as A1 and antibacterial activity tests were conducted for this alkaloid constituent compound using standard procedures. The minimum inhibitory concentration (MIC) of pure isolated compound A1 was evaluated against seven gram-negative bacteria has the MIC range against different indicator bacteria was 25.8 to $78 \mathrm{mg} / \mathrm{mL}$. This suggests that they have a wider antibacterial spectrum and they can be used for treating more than one infections caused by different gram-negative bacteria. Disc diffusion method was used and zones of inhibition, after respective incubation periods, were used to quantify antibacterial activity and results are summarized in table 1.

Table 1: The minimum inhibitory concentrations (MIC) for compound A1

$\begin{array}{clc}\text { No. } & \text { Organisms } & \text { Minimum inhibitory concentrations }(\mathrm{mg} / \mathrm{mL}) \\ 1 & \text { S. typhi } & 26.25 \\ 2 & \text { E. coli } & 25.8 \\ 3 & \text { S. paratyphi } & 77 \\ 4 & \text { S. typhimurium } & 49.9 \\ 5 & \text { Shigella spps } & 76 \\ 6 & \text { P. aeuroginosa } & 74.5 \\ 7 & \text { S. aureus } & 78\end{array}$

Compound A1 was obtained from methanol extract. Its molecular formula, $\mathrm{C}_{16} \mathrm{H}_{32} \mathrm{~N}_{2} \mathrm{O}$ was determined by negative LC-MS. In the negative LC-MS spectrum, the quasi-molecular ion peak was at m/z 268.89 [M-H]'.

In the IR $(\mathrm{KBr})$ spectrum the absorption band at $1711 \mathrm{~cm}^{-1}$ due to ketone and strong absorption band at 2921 $\mathrm{cm}^{-1}$ and medium absorption band at $1445 \mathrm{~cm}^{-1}$ due to saturated $\mathrm{C}-\mathrm{H}$ stretching.

The ${ }^{1} \mathrm{H}$ NMR spectrum (table 2) exhibited signal for the presence of two methines bearing of two tertiary amines at $2.75(1 \mathrm{H}, \mathrm{tt}, \mathrm{J}=4 \mathrm{~Hz})$ and $2.73(1 \mathrm{H}, \mathrm{dt})$. Signals at $\delta_{\mathrm{H}} 1.64-2.64(14 \mathrm{H}, \mathrm{m})$ are due to methylene protons. Signal at $\delta_{\mathrm{H}} 2.27(12 \mathrm{H})$ shows methyl proton attached to two tertiary amines group and signal $\delta_{\mathrm{H}} 0.96(3 \mathrm{H}, \mathrm{t})$ is due to methyl.

In the ${ }^{13} \mathrm{C}$ NMR spectrum, there were sixteen carbon signals. Signal at $\delta_{\mathrm{C}} 211.2$ represent ketone carbon and signal at $\delta_{\mathrm{C}} 67.5$ and $\delta_{\mathrm{C}} 63.5$ shows methine carbons bearing two tertiary amines group. Signals at $\delta_{\mathrm{C}} 43.85$ and $\delta_{\mathrm{C}} 44.2$ were assigned for four methyl substituent attached to two amines group. Signals at $\delta_{\mathrm{C}} 17.2,22,29.88,29.89$, $35,43.1$ and 45.1 are due to aliphatic carbons. Signal at $\delta_{\mathrm{C}} 13.88$ show methyl carbon. The multiplicity of each carbon atom was determined using DEPT-135 experiment. (See table 2)

All chemical shift data in the ${ }^{1} \mathrm{H}$ NMR, ${ }^{13} \mathrm{C}$ NMR, DEPT-135, IR and LC-MS spectra closely matched the tentative proposed structure for the compound A1 chemically: 1-(2,4-bis(dimethylamino)cyclopentyl)heptan-4one. (See fig 1)

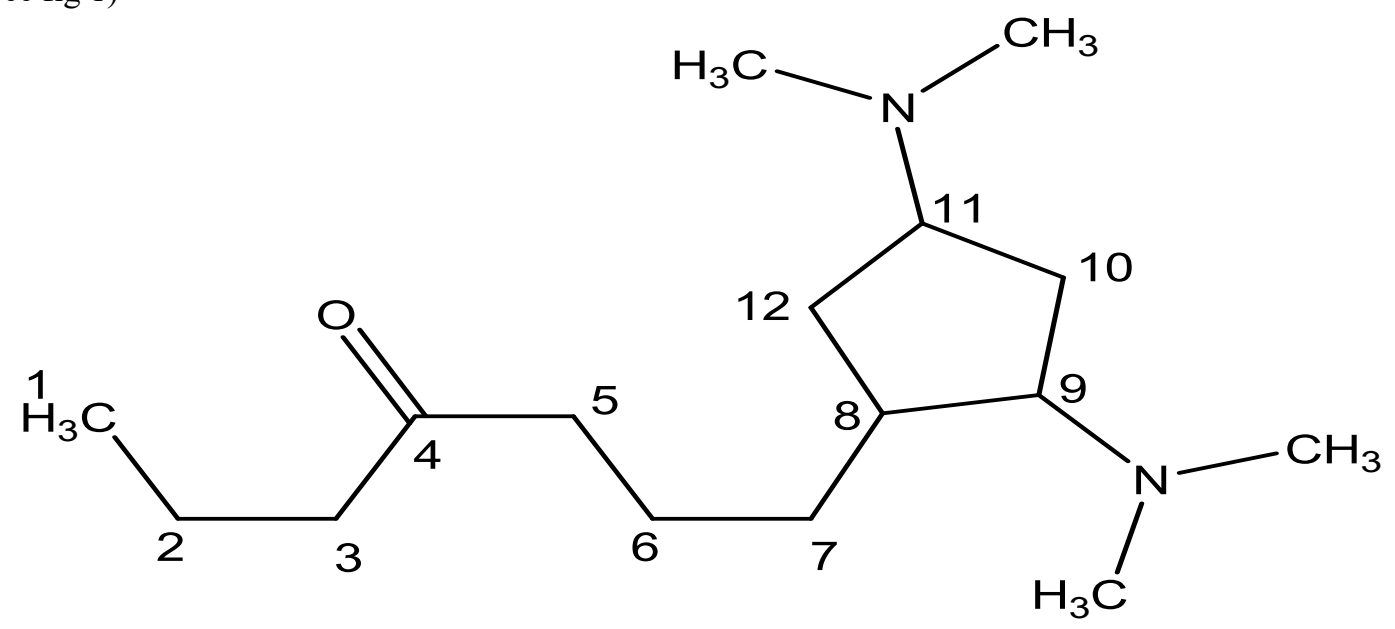

Fig. 1 The structure of compound A1 


\begin{tabular}{cccc}
\hline & Table $2{ }^{1} \mathrm{H}$ NMR, ${ }^{13} \mathrm{C} \mathrm{NMR}$ and DEPT-135 spectral data of compound A1 in $\mathrm{CDCl}_{3}$ \\
\hline Position & ${ }^{1} \mathrm{H} \mathrm{NMR}(\mathrm{ppm})$ & ${ }^{13} \mathrm{C} \mathrm{NMR}(\mathrm{ppm})$ & $\mathrm{DEPT}^{-135}$ \\
1 & $0.96(3 \mathrm{H}, \mathrm{t})$ & 13.88 & $\mathrm{CH}_{3}$ \\
2 & $1.64(2 \mathrm{H}, \mathrm{tq})$ & 17.2 & $\mathrm{CH}_{2}$ \\
3 & $2.46(2 \mathrm{H}, \mathrm{t})$ & 45.1 & $\mathrm{CH}_{2}$ \\
4 & - & 211.2 & Quaternary \\
5 & $2.64(2 \mathrm{H}, \mathrm{t})$ & 43.1 & $\mathrm{CH}_{2}$ \\
6 & $1.62(2 \mathrm{H}, \mathrm{tt})$ & 22 & $\mathrm{CH}_{2}$ \\
7 & $1.34(2 \mathrm{H}, \mathrm{dt} \mathrm{J}=2.2 \mathrm{~Hz})$ & 29.88 & $\mathrm{CH}_{2}$ \\
8 & $1.89(1 \mathrm{H}, \mathrm{m})$ & 32.5 & $\mathrm{CH}$ \\
9 & $2.73(1 \mathrm{H}, \mathrm{m})$ & 67.5 & $\mathrm{CH}$ \\
10 & $1.61(2 \mathrm{H}, \mathrm{dd})$ & 29.89 & $\mathrm{CH}_{2}$ \\
11 & $2.75(1 \mathrm{H}, \mathrm{tt}, \mathrm{J}=4 \mathrm{~Hz})$ & 63.5 & $\mathrm{CH}$ \\
12 & $1.55(2 \mathrm{H}, \mathrm{dd})$ & 35 & $\mathrm{CH}_{2}$ \\
14,16 & $2.27(6 \mathrm{H})$ & 43.85 & $\mathrm{CH}_{3}$ \\
\hline
\end{tabular}

\section{Conclusion}

This work resulted in isolation of one alkaloid constituent compound A1 from the medicinal plant Calpurnia aurea, the compound was identified as A1 chemically: 1-(2,4-bis (dimethylamino)cyclopentyl)heptan-4-one. The structure of the compound was characterized on the basis of spectral data $\left(1 \mathrm{H} \mathrm{NMR},{ }^{13} \mathrm{C}\right.$ NMR, DEPT-135, IR and LC-MS) as well as comparison with the literature data and the isolated an alkaloid constituent compound A1 have a wide range antimicrobial activity (MIC of 25.8 to $78 \mathrm{mg} / \mathrm{mL}$ ) against all tested bacteria strains.

\section{References}

[1] From Wikipedia, the free encyclopedia: https://en.wikipedia.org/wiki/Calpurnia_aurea

[2] Elibariki. E, Cecilia L. and Musa C. 2016, European Journal of Medicinal Plants. Evaluation of Antibacterial Activity of Five Selected Medicinal Plants in Tanzania against Gram Negative Bacteria 12(2): 1-7.

[3] Eloff J. A sensitive and quick microplate method to determine the minimal inhibitory concentration of plant extracts for bacteria. Planta medica. 1998;64(8):711-713.

[4] Pradeep A, Dinesh M, Govindaraj A, Vinothkumar D, Ramesh Babu NG. Phytochemical analysis of some important medicinal plants. Int J Biol Pharm Res 2014; 5: 48-50.

[5] Saleem M, Karim M, Qadir MI, Ahmed B, Rafiq M, Ahmad B. In vitro antibacterial activity and phytochemical analysis of hexane extract of Vicia sativa. Bangladesh J Pharmacol 2014; 9: 189-93. 